\title{
AIR LEAKS AFTER SURGICAL STAPLING IN LUNG RESECTION: A COMPARISON BETWEEN STAPLING ALONE AND STAPLING WITH STAPLE-LINE REINFORCEMENT MATERIALS IN A CANINE MODEL
}

Lee D. Roberson, MD, Donald E. Netherland, MD, Robin Dhillon, MD, and Bobby J. Heath, MD, Jackson, Miss.

The resurgence of interest in lung-volume reduction surgery in patients with chronic obstructive pulmonary disease has been accompanied by a recognition of the importance of preventing postoperative air leaks. ${ }^{1}$ Various materials have been used to buttress the staple line in lung reduction surgery, including everted walls of bullae, fibrin glue, blood patches, and strips of bovine pericardium. ${ }^{1}$ We conducted an experimental study to assess the effectiveness in preventing air leaks of stapling alone as compared with stapling with one of three reinforcement materials: bovine pericardium, ${ }^{*}$ expanded polytetrafluoroethylene (ePTFE) cardiovascular patch, $\dagger$ or a prototype ePTFE staple-line reinforcement material. $\neq$

Freshly harvested pairs of normal lungs from 24 adult

From the Division of Cardiothoracic Surgery, University of Mississippi Medical Center, Jackson, Miss.

Received for publication Dec. 23, 1997; accepted for publication March 18, 1998.

Address for reprints: Donald E. Netherland, MD, Division of Cardiothoracic Surgery, University of Mississippi Medical Center, 2500 North State St., Jackson, MS 39216.

Expanded polytetrafluoroethylene materials were supplied by W. L. Gore \& Associates, Inc., Flagstaff, Ariz.

* Per-Strips; Bio-Vascular, Inc., St. Paul, Minn.

$\dagger$ Gore-Tex Cardiovascular Patch; W. L. Gore \& Associates, Inc., Flagstaff, Ariz.

$\ddagger$ Seamguard Staple Line Reinforcement Material, W. L. Gore \& Associates, Inc., Flagstaff, Ariz.

J Thorac Cardiovasc Surg 1998;116:353-4

Copyright (c) 1998 by Mosby, Inc.

0022-5223/98 $\$ 5.00+0 \quad \mathbf{1 2 / 5 4 / 9 0 5 0 7}$ mongrel dogs (48 lungs) were used. The trachea was transected approximately $3 \mathrm{~cm}$ above the carina. A 7 $\mathrm{mm}$ endotracheal tube was inserted into the lung and secured with an umbilical tape. The endotracheal tube was then connected to a ventilator with a pressure gauge (Penlown, Ltd., Abingdon, United Kingdom). A surgical stapler (Ethicon GIA 55, Ethicon, Inc., Somerville, N.J.) was used to staple across the apex of each lung. In one lung of each pair (control), only staples were inserted. For the other lung in the pair, bovine pericardium, ePTFE cardiovascular patch material, or ePTFE prototype staple-line reinforcement material (eight lungs for each material) was attached to the stapler before firing and the staples were fired through the material, thereby creating a buttressed staple line that remained in the lung tissue.

The stapler was removed and the entire lung preparation, including the junction of the endotracheal tube and trachea, was immersed in normal saline solution. Positive pressure was gradually increased until one or more bubbles were visible at the staple line. The pressure (centimeters of water) at which the first bubbles appeared was recorded.

The results with respect to the pressure at which air leakage occurred in the control lungs as compared with the lungs in which the staple-line reinforcement materials were placed were statistically assessed with one-way analysis of variance and $t$ tests.

The pressure at which air bubbles were observed in the staple line varied considerably within the control group and each of the test groups. There were no significant differences among the three materials in the air-leakage pressure. However, for each of the three materials, the pressure at which leakage occurred was significantly higher $(p=0.004)$ than that at which air 
leaks appeared in the unreinforced staple line. In general, the effect of using a reinforcement material was that the air-leakage pressure increased by a mean of $10.8 \mathrm{~cm} \mathrm{H}_{2} \mathrm{O}$ over control values $(p=0.004)$. The staple lines reinforced with the prototype ePTFE material had the greatest mean difference in air-leakage pressure from the control staple lines $\left(11.8 \mathrm{~cm} \mathrm{H}_{2} \mathrm{O}\right)$; the values for the staple lines reinforced with bovine pericardium and ePTFE cardiovascular graft material were 11 and $9.6 \mathrm{~cm} \mathrm{H}_{2} \mathrm{O}$, respectively (differences not significant).

Our results indicate the importance of reinforcing the staple line in lung resection procedures to prevent air leaks. Use of a staple-line reinforcement material in lung reduction surgery has been described by Cooper ${ }^{1}$ and McKenna and associates ${ }^{2}$; others ${ }^{3}$ have not mentioned buttressing the staple line.

We did not find any differences between the stapleline reinforcement materials we studied in the pressure at which air leaks occurred. A larger study might reveal that one material is superior to the others. The choice of staple-line reinforcement material for clinical lung reduction surgery currently depends on several factors, including ease of use and biocompatibility. The ePTFE cardiovascular patch material is not indicated for use in lung surgery. Bovine pericardium strips must be soaked in saline solution and rinsed before implantation to avoid an inflammatory reaction in host tissue. Commercially available ePTFE staple-line reinforcement material (Seamguard Staple Line Reinforcement Material) requires no soaking or rinsing.

Host reactions to prosthetic materials used in lung resec- tion procedures have not been specifically studied. Bovine pericardium, however, has been associated with calcification, extensive inflammatory reactions, and formation of fibrous tissue in cardiac applications. ${ }^{4}$ Expanded PTFE produces a minimal inflammatory reaction. ${ }^{5}$ These data suggest that some form of staple-line reinforcement should be used. We believe the use of some type of reinforcement is most important in the diseased lung where air leaks may result in significant morbidity and prolonged hospital stays. The actual choice of material is dependent on the factors discussed above.

We thank Leonard Roseman, PhD, for performing the statistical analysis.

\section{REFERENCES}

1. Cooper JD. Technique to reduce air leaks after resection of emphysematous lung. Ann Thorac Surg 1994;57:1038-9.

2. McKenna RJ Jr, Brenner M, Gelb AF, Mullin M, Singh N, Peters $\mathrm{H}$, et al. A randomized, prospective trial of stapled lung reduction versus laser bullectomy for diffuse emphysema. J Thorac Cardiovasc Surg 1996;111:317-22.

3. Keenan RJ, Landreneau RJ, Sciurba FC, Ferson PF, Holbert JM, Brown ML. Unilateral thoracoscopic surgical approach for diffuse emphysema. J Thorac Cardiovasc Surg 1996;111: 308-16.

4. Dahn M, Lyman WD, Schwell AB, Factor SM, Frater RW. Immunogenicity of glutaraldehyde-tanned bovine pericardium. J Thorac Cardiovasc Surg 1990;99:1082-90.

5. Brewster DC. Prosthetic grafts. In: Rutherford RB, editor. Vascular surgery. 4th ed. Philadelphia: WB Saunders; 1995. p. 492-521. 